\title{
Measuring metals release and biological activity in decades old cast iron pipes subjected to a disinfectant change
}

\author{
J. Heberling \& P. Barron \\ Birmingham Water Works Board, Birmingham, Alabama, USA
}

\begin{abstract}
In an attempt to anticipate future, stricter disinfection by-products (DBPs) regulation, the Birmingham Water Works Board (BWWB) investigated the feasibility of replacing the primary disinfectant chlorine with chloramines. The purpose of this study was to determine if chloramines usage may increase lead and other metal residuals, which increase metal concentrations above healthy limits. Other utilities have observed an apparent correlation between a disinfectant switch from chlorine to chloramines and increased lead and other metal residuals.

A pipe rack was constructed with cast iron and lead piping and brass fixtures. The rack was designed to mimic a distribution system with twelve-hour flow (approximately 3000 gallons) and twelve-hour stagnation. The finished water was introduced to the pipe rack. Three corrosion inhibitors were tested before the introduction of chloramines to the pipe rack.

During a 2.5-year period, the cast iron pipes were sampled weekly for an array of parameters to determine degree of metal leaching. The metals sampled for were iron (total and dissolved), lead (total and dissolved), copper, and aluminum. These metals are common constituents in pipe scale and, if present in sampled water, can indicate pipe corrosion. Increased iron corrosion can lead to "red water," which is aesthetically undesirable. In addition, stagnant water in the cast iron pipes was sampled for heterotrophic plate counts (HPC) to indicate biological activity. These parameters were selected to measure metals concentrations leaching into water and the potential corrosivity of the water itself.

Keywords: corrosion inhibitors, chloramines, polyphosphate, orthophosphate, "red water".
\end{abstract}




\section{Introduction}

In July 2002, the District of Columbia Water and Sewer Authority's (WASA) routine tap samples for lead exceeded the action level of 15 parts per billion (ppb) [1]. Washington D. C., like many other municipalities, has lead piping throughout its distribution system (and in service lines) dating before the 1940s. The following monitoring period, WASA again exceeded the action level with a concentration of $40 \mathrm{ppb}$, requiring continuation of the public education program and lead service line replacement program [1]. WASA was required to continue full routine tap monitoring [1].

In January 2004, the Washington Post reported that the WASA had found elevated lead levels in the drinking water of more than 4,000 homes during 2003 testing [2]. Discovery of increased lead residual in WASA drinking water occurred in conjunction with the switch from chlorine to chloramines, as the primary disinfectant, in 2001 [3]. After exceeding the lead MCL from 2002 through 2004, WASA conducted full monitoring for lead and copper at customers' taps yearly [4].

In 2004, WASA added an orthophosphate corrosion inhibitor to reduce the drinking water lead levels. In 2006, the EPA approved application of an orthophosphate corrosion inhibitor as the final optimal corrosion control treatment [4].

The purpose of this study is to determine if chloramines could have a negative effect on the BWWB distribution similar to what was observed in Washington. Though the BWWB has made a concerted effort to remove lead elements from the distribution system, some still remain. Some older homes in the BWWB service area have lead service lines and plumbing, as well. Any process or chemical that increases lead dissolution could raise lead residuals leading to potential health concerns.

Additionally, the BWWB wanted to explore any other detrimental reactions of chloramines use aside from higher lead residual. These potential problems include:

- Increased bacterialogical activity measured through HPC sampling,

- Any increased metal corrosion, and

- Detrimental effects of restarting chlorine after use of chloramines (chlorine "burn out").

WASA used orthophosphate, which has a reputation within the water industry of promoting copper corrosion and "red water" (discoloration from iron corrosion). The BWWB needed to thoroughly examine all negative public health, public relations, and financial considerations before introducing chloramines to the Birmingham distribution system. To do this the BWWB built a Flow-Through pipe rack at the H. Y. Carson Filter Plant.

\section{BWWB Flow-Through}

The H.Y. Carson Filter Plant (CFP), located in Pinson, twenty miles north of Birmingham, Alabama (USA) provided the location and materials for this 
research. Built in 1972, the CFP supplies BWWB customers with up to 25.9 million gallons per day (mgd) of finished water. CFP's water source is Inland Lake; a low turbidity and alkalinity reservoir located twenty miles north of Pinson. Raw water supplied to the CFP flows through a sixty-inch $\left(60^{\prime \prime}\right)$ transmission line.

\subsection{Source water}

Inland Lake is a man-made reservoir located approximately thirty miles northeast of Birmingham, Alabama. The lake has a typical $\mathrm{pH}$ range of 7.0 to 7.5 at intake level. The water has low alkalinity (less than $25 \mathrm{mg} / \mathrm{l}$ as $\mathrm{CaCO}_{3}$ ) with trace amounts of dissolved iron and manganese.

\subsection{Flow-Through purpose}

A Flow-Through system is an effective way to measure metal leaching. A FlowThrough system differs from a pipe loop in that a loop re-circulates the same water over a given time period while a Flow-Through allows water to pass. In addition, a pipe loop focuses on material deterioration and does no effectively mimic the behavior of a distribution system or domestic plumbing [5]. Alternative names for Flow-Through systems include Flow-Through, FlowThrough rack and pipe rack.

The American Water Works Association Research Foundation (AWWARF) pipe rack development studies provided the first attempts to consistently and comprehensively evaluate metals leaching in drinking water supplies [5]. For this reason, a Flow-Through system was selected, as opposed to a pipe loop, because the emphasis of this study is on corrosion and corrosion control. The AWWARF pipe rack was developed for demonstration testing with an emphasis on comparing the effect of various corrosion treatments on metals residuals. Pipe racks can be used to detect differences in lead and copper levels associated with different types of treatments and can be used to determine optimum treatment approaches [5]. Pipe racks can also assess the secondary impacts of a treatment on a system's overall water quality and regulatory compliance [5]. Results from the 1994 AWWARF study indicated that metals levels may respond quickly to changes in incoming water quality due to treatment interruptions [5]. Additionally, pipe racks can be used as a tool for demonstrating potential problems resulting from operational changes on metals levels in the distribution system after full-scale treatment is implemented [5].

\subsection{Flow-Through construction and application}

The CFP staff assembled a Flow-Through pipe rack with a primary goal to assess corrosion potential of chloramines introduction. A pipe rack was constructed with cast iron and lead piping and brass fixtures (Figure 1). The rack was designed to mimic a distribution system with twelve (12) hour flow (approximately 3000 gallons) and twelve (12) hours stagnation. A reservoir and pump introduced chemicals before the water entered the rack piping. The design 
was inspired by the AWWARF study described in the previous section [5]. This pipe rack design was intended to give the best possible approximation of settings found in the BWWB distribution system.

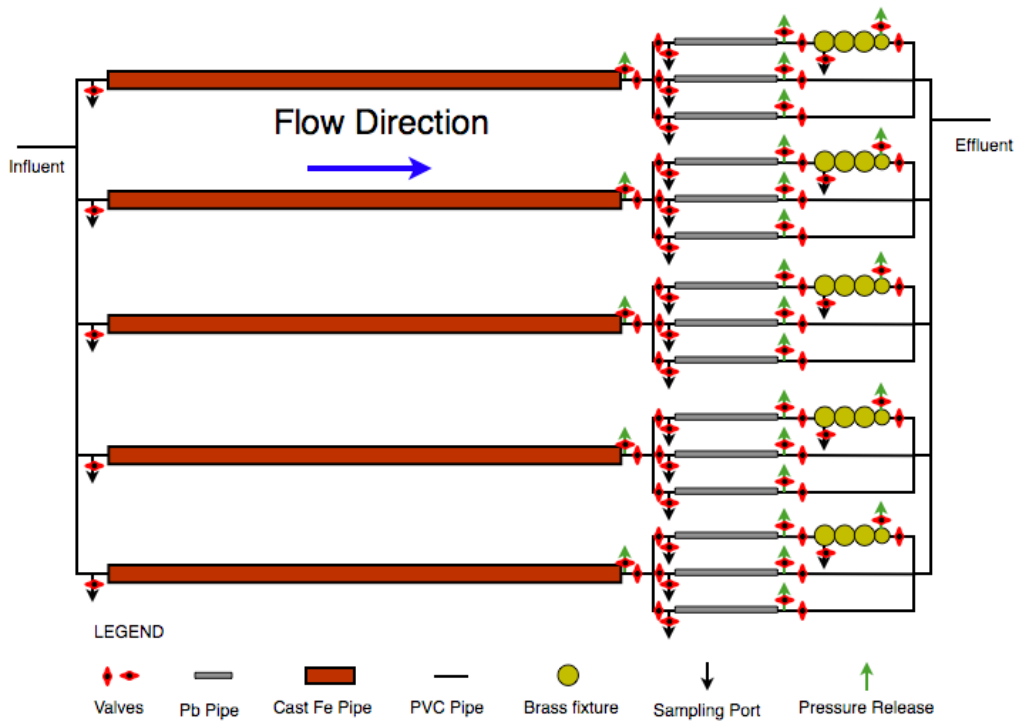

Figure 1: $\quad$ Carson pipe rack schematic.

The pipe rack, divided into five sections, each consisting of one ten-foot section of unlined cast iron pipe, three, 2.5-foot sections of lead service line pipe, and an assembly of brass fixtures. The cast iron pipes divided the influent into five sections. The flow subsequently branched into fifteen lead pipes. Ten of the branches fed directly to the effluent pipes. The remaining five branches fed directly to five series of brass fixtures. Each pipe and brass section was tapped with sampling valves. These valves separated the pipes during sampling, which occurred toward the end of the twelve-hour off cycle. All water exited through two effluent pipes measured by a pair of meters. No measurable leakage was noted throughout the study.

Flow-Through testing was performed in five independent sections of identical lengths and compositions. These sections all receive CFP finished (chlorinated) water and have no interconnections. Introduction of chemicals to the pipe rack was carefully controlled and no effluent was recycled to the plant.

The Flow-Through study was designed to investigate the following:

- The impact of phosphate addition to pipe scale stability,

- The impact of chloramines on pipe scale stability, and

- The impact of nitrification control strategies on pipe scale stability.

The cast iron pipes were sampled weekly for an array of metals to determine degree of leaching. These metals were iron (total and dissolved), lead (total and dissolved), copper, aluminum, and calcium. In addition, the cast iron pipes were 
sampled for heterotrophic plate counts (HPC). All samples collected were analyzed using EPA methods and approved equipment and techniques (See Table 1).

Table 1: $\quad$ EPA methods for each parameter.

\begin{tabular}{|c|c|}
\hline Parameter & EPA \\
& Method \\
\hline Aluminum & EPA \\
& 200.8 \\
\hline Calcium & EPA \\
& 200.8 \\
\hline Copper & EPA \\
& 200.8 \\
\hline Dissolved & EPA \\
Iron & 200.8 \\
\hline Total Iron & EPA \\
& 200.8 \\
& {$[1]$} \\
\hline Dissolved & EPA \\
Lead & 200.8 \\
& {$[1]$} \\
\hline Total Lead & EPA \\
& 200.8 \\
& {$[1]$} \\
\hline HPC & SM \\
& $9215-\mathrm{B}$ \\
\hline
\end{tabular}

All pipes were sampled weekly for several field parameters including: $\mathrm{pH}$, temperature, dissolved oxygen, turbidity, free chlorine, total chlorine, true color, apparent color, and UV 254.

The BWWB tested three phosphate inhibitors (including pure orthophosphate) to determine performance in such areas as metal leaching. The blends were a 70/30 polyphosphate-orthophosphate mixture and a 30/70 polyphosphate-orthophosphate mixture. More than 2.5 years of data was collected comparing the three corrosion inhibitors at concentrations ranging from 2.0 - $4.0 \mathrm{ppm}$ (see Table 2). The polyphosphate blends were discontinued after 17 months due to increased lead residuals in the lead and brass fixtures [7]. Chloramines were generated only in the presence of pure orthophosphate.

Ammonia was introduced to the rack to produce chloramines 23 months into the study. Excess ammonia was added in an attempt to encourage growth of nitrifying bacteria or at least provide an environment where nitrification could occur. There was no evidence of growth of nitrifying bacteria when the chlorine "burn out" was started. The "burn out" was achieved by discontinuing introduction of ammonia in the Flow-Through rack. This is similar to standard procedure for eliminating nitrifying bacteria in a chloraminated distribution system. 
Table 2: $\quad$ Duration of corrosion inhibitor and disinfectant pairs.

\begin{tabular}{|c|c|c|c|}
\hline $\begin{array}{c}\text { Corrosion Inhibitor - } \\
\text { Disinfectant }\end{array}$ & Parameters & $\begin{array}{c}\text { Pipes/ Fixtures } \\
\text { Sampled }\end{array}$ & $\begin{array}{c}\text { Duration of Sample } \\
\text { Collection }\end{array}$ \\
\hline $\begin{array}{c}\text { Polyphosphate Blend } \\
70 / 30-\text { Chlorine }\end{array}$ & $\begin{array}{c}\text { Field Parameters(Table 2) } \\
\text { Total Pb,Total Fe, Cu, Al }\end{array}$ & $\begin{array}{c}\text { All Pipes and } \\
\text { Fixtures }\end{array}$ & 11 Months \\
\hline $\begin{array}{c}\text { Polyphosphate Blend } \\
30 / 70-\text { Chlorine }\end{array}$ & $\begin{array}{c}\text { Field Parameters(Table 2) } \\
\text { Total Pb,Total Fe, Cu, Al }\end{array}$ & $\begin{array}{c}\text { All Pipes and } \\
\text { Fixtures }\end{array}$ & 6 Months \\
\hline $\begin{array}{c}\text { Orthophosphate - } \\
\text { Chlorine }\end{array}$ & $\begin{array}{c}\text { Field Parameters(Table 2) } \\
\text { Total Pb,Total Fe, Cu, Al }\end{array}$ & $\begin{array}{c}\text { All Pipes and } \\
\text { Fixtures }\end{array}$ & 6 Months \\
\hline $\begin{array}{c}\text { Orthophosphate - } \\
\text { Chloramines }\end{array}$ & $\begin{array}{c}\text { Field Parameters(Table 2) } \\
\text { Total Pb,Total Fe, Cu, Al }\end{array}$ & $\begin{array}{c}\text { All Pipes and } \\
\text { Fixtures }\end{array}$ & 6 Months \\
\hline $\begin{array}{c}\text { Orthophosphate - } \\
\text { Chlorine (burn out) }\end{array}$ & $\begin{array}{c}\text { Field Parameters(Table 2) } \\
\text { Total Pb,Total Fe, Cu, Al }\end{array}$ & $\begin{array}{c}\text { All Pipes and } \\
\text { Fixtures }\end{array}$ & 2 Months \\
\hline
\end{tabular}

\section{Metals release and biological activity in the cast iron pipes}

Data collected from the Flow-Through cast iron pipes will be used to determine relative amount of pipe scale metal release and biological activity from:

- chlorinated water treated with polyphosphate blends,

- chlorinated water treated with orthophosphate,

- chloraminated water treated with orthophosphate, and

- chlorinated water treated with orthophosphate (chlorine "burn out").

The cast iron pipes were sampled weekly two years for total iron, dissolved iron, aluminum, copper, lead, calcium, $\mathrm{pH}$, true color, apparent color, temperature, dissolved oxygen, turbidity, chlorine residual, and HPC. These parameters were compared to determine which corrosion inhibitor is most effective at resisting or preventing corrosion and which metal was more apt to enter solution under each condition. In addition, the data should indicate whether chloramines introduction aggravated corrosion in the Flow-Through rack. HPC samples will reveal degree of biological activity that was present throughout the study.

\subsection{Phosphate and bacterial growth}

A few reports suggest that phosphates increase HPCs and legionellosis outbreaks when introduced to distribution systems [6]. Other studies have found a decrease in HPC with the introduction of phosphates [6].

\section{Results of the BWWB Flow-Through}

\subsection{Copper and lead}

There was little discernable difference in copper and lead (total and dissolved) residuals in any combination of corrosion inhibitor and disinfectant. In fact, over $95 \%$ of all samples collected for copper, aluminum, and lead (total and dissolved) were below detection limits of the method used. 


\subsection{Aluminum and iron}

Aluminum residuals began to decline after the introduction of the first polyphosphate blend within 10 months. The vast majority (over 95\%) of all samples after 10 months showed total aluminum levels at or below $0.2 \mathrm{ppm}$ regardless of inhibitor and disinfectant combination (Figure 3). Total iron samples showed similar results. After 8 months only two samples showed total iron concentrations above 1 ppm regardless of inhibitor and disinfectant combination.

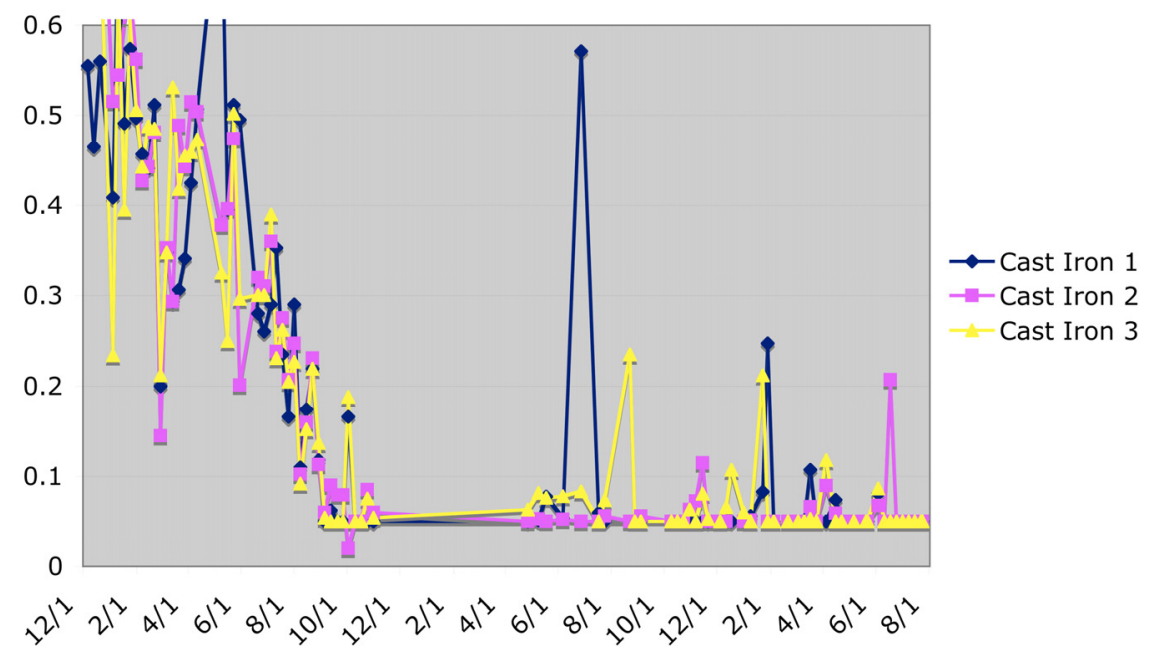

Figure 2: $\quad$ Total aluminum concentration ( $\mathrm{ppm})$.

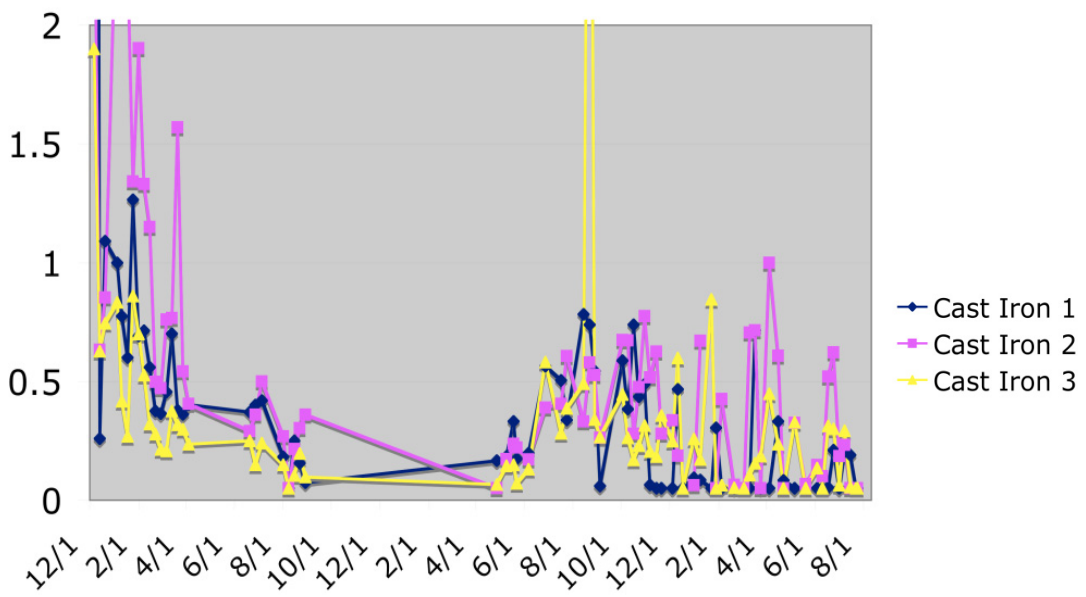

Figure 3: Total iron concentration (ppm). 


\subsection{HPC}

The heterotrophic plate count (HPC) was used to approximate the number of live heterotrophic bacteria in a water sample and provides useful information about water quality. HPC is a microbial count method using colony formation, on culture media, to approximate the levels of bacteriological activity. HPC, however has limitations. HPC data does not provide clues for sources or types of organisms present in samples. In addition, HPC data only measures number of organisms which can be cultured.

The HPC data indicated swings in biological activity throughout most of the study. There was a considerable reduction of biological activity during the chlorine 'burn out phase' (A in Figure 5).

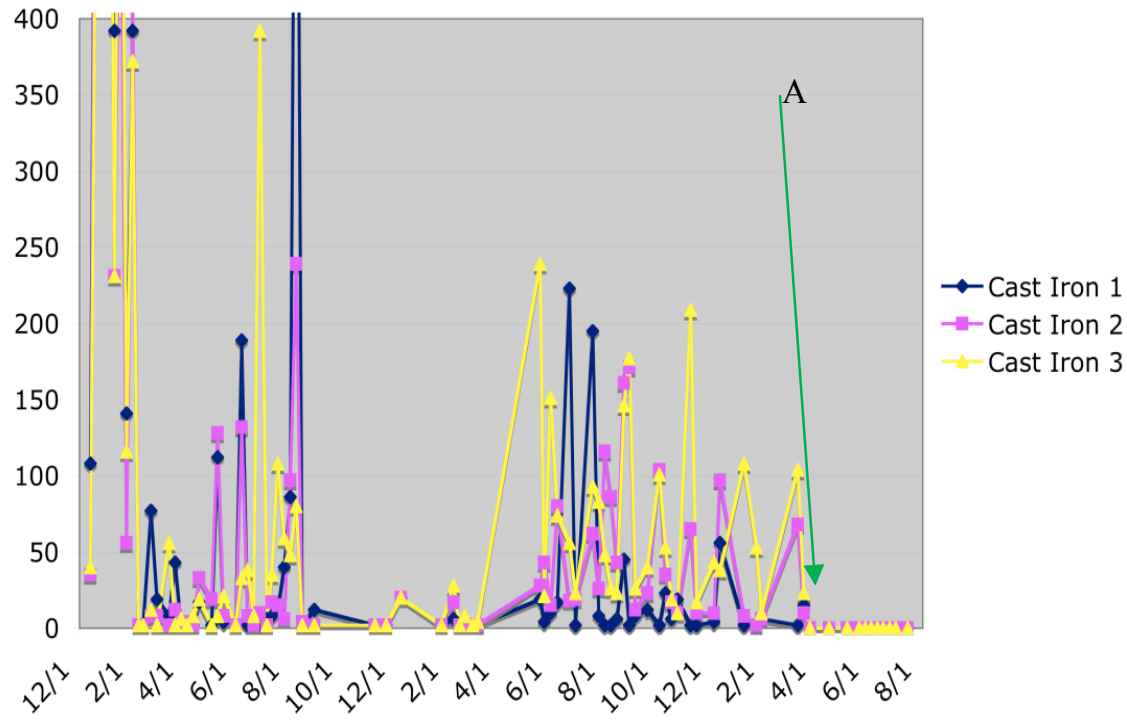

Figure 4: $\quad$ HPC in $\mathrm{cfu} / \mathrm{mL}$.

\section{Conclusions}

The polyphosphate corrosion inhibitors tested appeared to be effective in preventing copper, aluminum and iron corrosion in cast iron pipes in chlorinated water. The BWWB suspended use of the polyphosphates when lead residuals rose in other locations of the pipe rack. Orthophosphate was effective in preventing corrosion in chlorinated or chloraminated water. There was no evidence of "red water" resulting from the use of orthophosphates.

HPC numbers were greatly reduced during the chlorine "burn out" phase. This possibly resulted from the elimination of nitrogen metabolizing bacteria, which may have become prolific during the use of chloramines. 


\section{References}

[1] United States Environmental Protection Agency (USEPA). 2004. Action Plan to Reduce the Occurrence of Lead Leaching from Service Lines, Solder, or Fixtures into Tap Water In the District of Columbia and Arlington County and Falls Church, Virginia. Prepared by: USEPA, Region 3 Washington Aqueduct, US Army Corps of Engineers District of Columbia Water and Sewer Authority, Washington D.C.

[2] Tiemann, M. 2005. "Lead in Drinking Water: Washington, DC, Issues and Broader Regulatory Implications." Congressional Research Service (CRS) Report, Number RS21831.

[3] Edwards, M., and A. Dudi. 2004. "Role of Chlorine and Chloramine in Corrosion of Lead-Bearing Plumbing Materials.” Jour. AWWA, 96 (10) 6981.

[4] USEPA. 2008. Annual Compliance Report for Public Water Systems in the District of Columbia During Calendar Year 2008. Ground Water and Enforcement Branch (3WP22) USEPA Region III, Washington D.C.

[5] American Water Works Association Research Foundation (AWWARF). 1994. Development of a pipe loop protocol for lead control. Denver, CO.

[6] Appenzeller, B. M. R., M. Batté, L. Mathieu, J.C. Block, V. Lahoussine, J. Cavard, and D. Gatel. 2001. "Effect of Adding Phosphate to Drinking Water on Bacterial Growth in Slightly and Highly Corroded Pipes." Water Res., 35:4:1100-1105.

[7] Heberling, J., P. Barron, and R. Peters. 2009. "Pipe Flow-Through Investigation: Determining Potential Water Quality Problems Involved with Switching from Chlorine to Chloramines at the Birmingham Water Works Board (BWWB) Part II.” Proceedings, 2009 WQTC, Seattle; Washington, November 15-19. 